\title{
REVITALIZING UNION ACTION: THE IMPACT OF YOUTH COMMITTEES IN A PUBLIC SECTOR LABOUR FEDERATION IN QUÉBEC
}

\author{
Mélanie Laroche \\ Assistant Professor, \\ School of Industrial Relations, \\ Université de Montréal \\ Montréal, Québec, Canada
}

\author{
Mélanie Dufour-Poirier \\ Assistant Professor, \\ School of Industrial Relations, \\ Université de Montréal, \\ Montréal, Québec, Canada
}

\begin{abstract}
This article examines the revitalization of a union federation's capacity to represent young workers. It presents a qualitative study of the role and impact of one of the most developed forms of youth involvement in a union, youth committees. It first analyzes the extent to which these committees helped put the concerns of members under the age of 30 on the union federation's agenda and fostered their participation in its internal life. Second, it examines the ways in which these committees initiated a degree of change in the federation at the institutional level. Overall, our findings indicate that youth committees were able to question existing practices and initiate a degree of union change. However, the disagreements expressed by the young workers tended to remain confined within these parallel structures, thus limiting their potential to change the representative capacity of the federation.
\end{abstract}

\section{INTRODUCTION}

7 his article examines the effectiveness of the representation strategies used by a public sector union federation in Québec to connect with members under the age of 30 . The aim of the article is twofold. On an empirical level, it contributes to reflections on the problems faced by unions with regard to mobilizing and retaining young workers and the place they hold in union structures. This problem relates to the increasing difficulty confronted by unions to integrate the diverging interests of the labour force into their agenda and the failure of unions to engage with young workers (Peetz 2010; Vandaele 2012). In particular, we analyze whether or not youth committees help better integrate these workers into union life and union structures. On a theoretical level, we seek to shed light on the impact of actors' strategies on union renewal, 
while also examining the impact of the institutional framework on actors' capacity to initiate change.

In line with studies by Mahoney and Thelen (2010) and Lévesque and Murray (2010), we put forward an interpretation centred on the actor's capacity to act as an agent of change. We set out to confirm our basic premise that unions are dynamic actors capable of initiating change at the institutional level (Campbell 2004). The institutional entrepreneur is an actor that can combine practices in an innovative way and communicate new ideas so as to facilitate transitions associated with change. In our view, the crisis of unionism stems not only from external conflicts (e.g., impact of neoliberal restructuring on workers' capacities for collective action, and the weakness of the left), but also from internal conflicts that have an impact on the evolution of the union movement. Admittedly focusing on the latter, we thus consider unions as being able to effectively mobilize their resources to change existing structures and practices and adapt them to their needs.

Based on that, we set out to determine in what ways and by what means youth committees have helped improve and change the representative capacity of the union federation under study. Through in-depth interviews, we examined the capacity of this federation to maintain active links with union activists under the age of 30 and to accord them a place in its structures. The goal was not to examine all of the practices put in place by this federation to improve its ability to represent young members. Rather, we analyzed the role and impact of one of the most developed forms of union involvement among young workers, namely youth committees. Thus we analyzed to what extent these youth committees have helped put the concerns of workers under the age of 30 on the federation's agenda and have integrated young workers into its structures. We also examined the ways in which youth committees have changed the federation, that is, how they have led to change its practices, structures and strategic priorities.

Our analysis is thus in line with studies on the capacity of the union actor to promote group cohesiveness and to reconstruct its representative capacity, power and legitimacy by mobilizing its resources (Lévesque and Murray 2010). Overall, our findings show that the youth committees were able to initiate change in the existing practices, structures and priorities of this federation. However, the disagreement expressed by young workers usually remained confined within these parallel structures, which limited their potential to change the federation. This change therefore remains incomplete. Our findings infer that it is as yet too early to make a definitive judgement regarding the capacity of youth committees to initiate lasting change at the institutional level.

This article is presented in four parts. First, we will review the available literature dealing with young workers' involvement in the labour movement, in Québec in particular. Second, we will explain the methodology used in our 
study. Third, we will present our findings. Lastly, we will present some considerations that have emerged from our study.

\section{YOUNG WORKERS' INVOLVEMENT IN UNIONS}

The contextual factors that determine the representative capacity of unions are evolving (Lévesque and Murray 2010). Regarding young workers, past studies have mostly focussed on picturing the bleak prospects of their unionization. Very few studies expose their involvement with unions once unionized (Tailby and Pollert 2011; Vandaele 2012). However, young members should not be seen as a monolithic bloc. While the definition of worker cohorts varies depending on the author (Paquet 2005; Peetz 2010), two groups of young workers emerge with regard to union behaviour. On the one hand, young workers aged 15 to 21 are more inclined to resort to the "exit" strategy to resolve their problems at work. On the other hand, young workers aged 22 to 29 show a higher propensity for collective action. These figures correspond to statistics indicating a decrease in the rate of atypical and precarious employment in Québec among young workers aged 25 and older (Gauthier 2011). Overall, however, a drop in union density has been observed among young workers in Anglo-Saxon and European countries (Freeman, Boxall and Haynes 2007). Two explanations have been put forward regarding this phenomenon.

The first refers to the characteristics of young workers. The explanations put forward in recent years have suggested that the low propensity of young workers to become unionized or to participate in union life is due to either: a political ideology that conveys a rather negative opinion of unions (Brown 1992); a multiplicity of senses of belonging (Giddens 1990); new social causes which are not necessarily connected to the workplace (Inglehart 1997); and a general disengagement from any form of political participation, including union action (Bentley and Oakley 1999). Paquet (2005) revealed that young workers in Québec perceive the functions and services in place in unions as somewhat irrelevant. These workers are more inclined to seek immediate results rather than endorse social or societal demands. They give less importance to job security and employee benefits than older workers. Also, their rather negative employment experience has also led them to doubt the usefulness of unions. Precarious employment, to which they have often fallen prey, has thus negatively coloured their opinion of unions. Lastly, union officers in charge of delivering messages often belong to older generations and give low priority to the needs of young workers. Overall, these pressures invite unions to diversify their practices to encourage young workers to become more involved in union life (Vandaele 2012).

The second explanation suggests that the position of young workers in the labour market poses serious challenges for unions, that is, structural challenges 
with regard to collective representation. More specifically, young workers often find themselves in industry sectors in which it is particularly difficult to unionize workers and in which working conditions tend to be quite poor (e.g., service industries). Moreover, the low rate of unionization stems from a higher turnover rate among these workers, who are often still students (Usalcas and Bowlby 2011). Once unionized, it is also easier for these workers to resort to the "exit" strategy than to attempt to resolve problems at work through collective means. In Québec, young workers are also less attached to their jobs (Paquet 2005). Why try to resolve problems in a temporary work setting? This question arises, in particular, for the students among this generation.

Nevertheless, there is little empirical evidence supporting young workers' low propensity to participate in union life. On the contrary, recent studies have tended to show that young workers do not challenge the relevance of unions in the workplace, but rather question the pertinence of traditional pressure tactics (e.g., strikes) (Freeman, Boxall and Haynes 2007; Gómez, Gunderson and Meltz 2002). It is then less than obvious that young workers are no longer interested in traditional organizations like trade unions (Vandaele 2012) and are increasingly individualistic (Peetz 2010). In Québec, recent uprisings during the Maple Spring 1 testify to the opposite. Empirical results have also attested to a genuine effort on the part of unions to connect with young workers through alliances with social movements (Nissen 2004). Moreover, the increased use of social media has facilitated exchanges between union members of all ages and thus reduced intergenerational tensions within unions (Firestein and King 2010). Waddington and Kerr (2002) have also reported various measures implemented by unions to organize young workers, and to encourage them to participate in union life. These measures include: lowering union dues; holding recruitment campaigns on campuses and during public events (e.g., festivals); and training young workers to lead organizing campaigns among their colleagues. Whether those attempts have paid off remains to be seen.

Other examples include organizing informal meetings which are run in a more flexible manner, using less official language so as to encourage young workers to increase their participation in union activities, and incorporating issues that reflect these workers' concerns into the union's agenda (e.g., workfamily balance and precarious employment) (Yates 2004). Brown, Johnson and Jarley (2005) also point out the importance of maximizing the frequency of personal exchanges within union structures in order to represent the needs of young workers and strengthen solidarity, particularly during conflicts. These authors infer that when young workers are in contact with delegates of their own age, they tend to feel that their concerns have been heard by the union, have a better understanding of how the union operates, see themselves as being better represented, and eventually get more involved. Such contact would therefore strengthen the relationship of trust between young workers and the union. These 
innovations confirm that some unions are truly making an effort to better integrate young workers into union life and to encourage their participation. Such efforts, however, do not guarantee young workers a place in union structures or a significant role in the union's decision-making processes. Yet recent findings (Vandaele 2012) have revealed that youth representatives across Europe find their confederations' responsiveness and commitment to organizing young workers to be inadequate, confirming once again their dissatisfaction and unfulfilled desire for unionization.

That being said, it becomes relevant to examine the strategies implemented by the union federation under study to become more responsive to young workers' particular interests and needs, and encourage them to participate in its activities. More specifically, we analyze the capacity of youth committees to change the federation's practices and spur change at the institutional level, in an effort to improve the representation of young members. These questions are central to our analysis.

\section{METHODOLOGY}

This study was based on a qualitative methodology. It involved a mid-sized union federation in Québec's public (health) sector that incorporated youth committees into its structure at various levels (local, regional and national). The central or "national" youth committee was formed in the early 2000's and included five elected leaders. At the time of the study, this committee had ties with various youth committees at the regional and local levels. However, youth committees were not in place at the local level in all regions. The composition of these committees varied but usually included three to four elected union leaders.

The youth committees were formed with the aim of encouraging young workers to participate and become more involved in the federation, in particular with regard to the development of policies and strategic orientations at various levels. The goal was to use these committees to foster bidirectional exchanges between federation leaders and young workers. The central youth committee also had the mandate to communicate the day-to-day concerns of young workers to the members of the federation's executive committee and to meet the requests that the latter might entrust to it, in particular, with regard to mobilization. In practice, however, two questions arose: (1) had these committees made it possible to better connect with young workers and identify their particular interests and needs? and (2) had the suggestions made by youth committees led to changes in the practices, structures and priorities of the federation? In other words, what kind of work had youth committees been able to perform since they were created? Did the youth committees really help boost young members' involvement into the federation's life? 
In order to address these questions, we held five initial interviews with the federation leaders in the fall of 2009. The aim was to find out what concerns were on the youth committees' agenda and what actions they had taken. In the spring of 2010, we held in-depth interviews with six elected leaders from the central youth committee. These interviews allowed us to better grasp three themes and the challenges related to them: (1) the factors that foster young workers' active participation in federation life; (2) the perceived impact of the youth committees on the decisions made by the federation; and (3) the possible avenues for renewal in the federation with regard to its young activists. At the same time, we also held focus groups to investigate the point of view of 90 members under the age of 30. Lastly, we examined documents dealing with the youth committees and the participation of young workers in the federation.

The findings that emerged from stage one of this still ongoing study highlighted the capacity of youth committees to change some of the practices of the federation. The interviews brought out two main issues. The first referred to the intermediating role played by the youth committees. The second concerned the ambiguities regarding the roles played by these committees and the expectations raised by them.

\section{AGENTS OF EDUCATION OR VEHICLES FOR CHANGE?}

First, we examined whether the youth committees had really helped the federation to connect with young workers, that is, to increase their level of activism and their involvement in the life of the federation. The federation leaders felt certain that youth committees had helped the federation meet this goal. While the objective, at the outset, had been to "follow the trend started by other union organizations in Quebec," it appears that, over recent years, youth committees had managed to take on a more important role within the federation:

For many years, the youth committees in our federation were purely cosmetic. It was just "a trend." We hadn't really put actual mechanisms in place to make the committees effective. We merely sent young activists to conferences to open them up to new horizons. But recently there's been a real desire to do something to get young members more involved because we've realized that there's nobody to take over for us as we get older. (trans. Interview \#3 with a local trade unionist).

Our interviews also brought out the fact that contact between young members had helped the latter to better identify with the federation, thus lowering the risk that they would see the federation as "representing workers from older generations." Youth committees were urged to organize more informal meetings and to present themselves as places where exchanges could 
take place in a less official manner in order to encourage young workers to participate in union life. One of the respondents made the following comment in this regard:

We don't understand anything in the meetings and the jargon used in there is way too formal! There is not enough flexibility while directing the meetings! Roughly speaking, we don't feel that we are enough endowed to really get involved in our union. (trans. Interview with a young militant in focus group \# $6)$.

Our findings also revealed that these committees had, to date, been effective vehicles for disseminating information among young activists. To this end, they had helped make federation language more accessible to young members, who are often unfamiliar with the jargon used in meetings. In this respect, the overwhelming majority of the members under 30 years of age who participated in the survey positively rated the committees' capacity to communicate the specific messages and proposals they were asked about. The young representatives also used new channels of communication, such as social media (e.g., Facebook, Twitter), to reach their members, even if simply to invite them to a happy hour for young workers, for example. One of the respondents made the following comment in this regard:

We know that young people like using social media. Distributing the union newspaper, it doesn't work anymore! It's not trendy among young workers. Most of all, the message doesn't get through with traditional means. Our Facebook page is very popular. At the same time, we also have to reinforce our visibility locally. (trans. Interview \#5 with a local trade unionist).

In addition, the respondents clearly indicated that personal contacts constituted an effective strategy for convincing young workers to participate in federation activities. They also recognized that such contacts were an effective means for young workers to obtain needed information (e.g., regarding the collective agreement or insurance matters). In short, the respondents considered that, overall, the youth committees had helped strengthen the federation's capacity to disseminate information among members under the age of 30 .

The question thus arose as to whether these committees also made it possible to convey the young workers' messages such that these could be taken into account in the federation's policies and strategic orientations and ultimately change the federation. It should be recognized that the primary goal of youth committees was precisely to identify the concerns of members under the age of 30. The information gathered was to be used to inform federation decisions, including those made by the local and regional executive committees. In this regard, our interviews revealed that the influence exerted by the youth 
committees often depended on the degree of openness of the elected leaders on the federation's regional executive committees. This was important, given that more often than not, these elected leaders were from older generations. In some local unions, where an executive position was reserved for one young personusually the leader of the local youth committee, young representatives had a greater influence within the executive. However, in some local executive committees, although a young representative was always present, some reluctance remained with regard to giving young workers a voice. As one young activist put it:

It's really great that there are young people on the executive, but we can't disturb the habits (of the older members) too much and we have to stay in line. (trans. Interview with a young militant in focus group \# 2 ).

To conclude, somewhat of a gap could be observed between the ideas put forward by the central versus the local leaders. At the central level, youth committees were expected to fulfil specific roles: disseminate information to members under the age of 30, inform the elected representatives (at the local, regional and central levels) of the particular concerns of young workers and encourage participation and activism among them - in short, prepare the new generation to take over from the older generation. These committees were seen as an essential component of the federation, one that allowed it to better represent the diverse interests of its members. At the local level, on the other hand, our findings revealed that the youth committees were not perceived the same way by all the local leaders: apparently, some of them tended to prevent youth committees from effecting change in local practices and priorities.

\section{EXPECTED ROLES AND RAISED AMBIGUITIES}

Second, we asked about the committees' capacity to meet the expectations of young members and help change the federation's practices, structures and agenda. In this regard, several respondents felt that the mandates that had been entrusted to committees were too narrow to be able to effect lasting change. In fact, somewhat of a gap also existed here between their expectations and those of their federation. Although they accepted their responsibility to help prepare the next generation to take over from the older one, and to be consulted on the issues affecting young workers, some committees expressed the desire to be "the voice" of young workers locally. Some committees condemned "their modest influence in some local unions."

The local level appeared to be the favoured locus of action for young members. Our findings show that the concerns of young workers conveyed at this level revolved around the day-to-day issues directly affecting them (e.g., 
work organization or work time arrangements). Young members who were involved at the local level perceived their actions as being more effective, as helping, for example, to bring concrete improvements to their working life, which appeared to be one of the most important concerns of this generation. In practice, there appeared to be a cycle of marginalization of young representatives in the decision-making structures of the federation. By that, we mean that the low level of participation of young members in activities and meetings did not allow their representatives to influence the decisions made by the federation. Consequently, the action undertaken by youth committees was perceived negatively and quite ineffectual. As a young activist said:

What is the purpose of getting involved in our local committee?! Older militants always block our projects and deny our concerns! (trans. Interview with a young militant in focus group \# 8).

And yet, the comments gathered confirmed the capacity of youth committees to spark an interest in federation life among young workers and help familiarize them with its practices.

In line with Paquet's view (2005), some respondents felt that integrating young workers into the union would require more than launching new structures (such as youth committees) since it involves in-depth changes in union's programs and practices. Without any real participation, beyond consultation, in the decision-making processes of the local or regional executives, the impact of youth committees proved to be rather limited with regard to the federation's ability to change its representative capacity. Our survey respondents thus called for a greater influence on the part of youth committees, an influence that would go well beyond the roles with which they had been entrusted to date.

Lastly, our interviews confirmed the importance of clarifying the roles assigned to the youth committees, and, especially, of allowing them to exert a significant influence on the federation's strategic orientations in order to prevent the possible demobilization of young activists. A serious warning sign was identified in this respect which could be referred to as "dangerous patience." Indeed, several respondents underscored the difficulties they had encountered when trying to communicate the concerns of young members to local union executives and suggest initiatives for resolving the problems affecting them at work. These obstacles had caused more than one young member to decide to wait until some elected leaders were going to give up their positions so that they could finally take action to address the practical local and short-term needs and priorities of young workers. Several elected leaders were expected to retire in the next five years, which would necessarily bring about a renewal in the union's executive. 
However, this waiting on the part of young representatives involved several risks. On one hand, it deprived the local unions and the federation of the positive effects of internal debate, which could force it to renew federation discourse, practices and structures. On the other hand, it impeded the transfer of knowledge and expertise between the different generations of representatives. Moreover, it did not address the apathy of young members who had been disappointed by their brief union experience and who would themselves be getting older as the years passed. These findings led us to the conclusion that there was a need in this federation for an educational and awareness-raising campaign regarding the importance of integrating young members and preparing them to take over from the older generation, thus ensuring the federation's renewal.

\section{CONCLUSION}

The process of integrating young workers into the union federation under study appeared as yet to be incomplete. Despite the messages put out by the federation leaders regarding youth committees and their openness to them, there still appeared to be some reluctance with regard to the participation of young members in the federation's internal structures. In order to become more involved, young workers seemed to feel the need to be able to influence the decisions made by their federation and their local unions. Hence the importance for the youth committees of communicating the specific concerns of young workers and helping to integrate these concerns into the federation's projects, struggles and structures. The question of the roles entrusted to the youth committees also remained a sizeable challenge. However, despite these difficulties, a degree of change appeared to be taking place at the institutional level. Indeed, the youth committees had already put forward new ideas and initiated changes in representation practices. The impacts of these changes, however, were not yet significant at the institutional level.

Moreover, our findings did not reveal an overall questioning on the part of the youth committees regarding the way the federation operated. Indeed, our interviews did not bring out a shared desire on the part of young members to change the underlying aim, objectives and roles of the federation. Rather, the comments gathered attested to changes that corresponded to the process of institutional layering (Mahoney and Thelen 2010), whereby new practices and ideas are "layered" on top of pre-existing ones so as to complete them. In this case, the youth committees had adopted a new set of practices that influenced the way they promoted collective action and the mobilization of young members, locally and nationally. For example, the committees were using newly available communication channels and spaces for dialogue in order to carry out their 
intermediating role between young members and their leaders. Perceived change is nevertheless still embryonic.

We therefore recognize the possibility for the youth committees, in their role of mediating differences, to slowly change the representative capacity of the federation under study. These committees had been able to bring in ideas, practices and structures from the outside and to adapt them to their federation. Our findings also showed quite clearly that the youth committees' ability to bring about change depended on their capacity to harmonize the proposed representation practices with those already in place. Hence, once again, revealing the importance of analyzing the actions taken by various groups of actors to explain institutional change and the way it is disseminated.

In other words, the youth committees could be considered to be institutional entrepreneurs in the process of maturing, as they had so far been able to challenge existing practices, express their disagreement and bring about change. However, while the youth committees thus constituted a locus of experimentation for the federation, our findings also revealed that the disagreements expressed usually remained confined within the limits of these committees. There was thus a need for dialogue, consultation, and the sharing of ideas at all levels of the federation, from the top of the hierarchy down to its activist base and vice versa. This study thus supports the need to fully disseminate information to all members and to effectively integrate the diverse concerns and needs that coexist within a union, including those of young workers. After all, very little consistent evidence suggests opposition in principle to unions among young workers. Empirical results show that engagement in political activities seems to go hand in hand with unionism (Vandaele 2012). The political outburst observed in Québec last spring revealed that new generations are politicized and interested in social debate. Perhaps part of the failure is the way unions connect with young workers.

\section{ACKNOWLEDGMENTS}

The authors would like to thank the two anonymous reviewers and Patrice Jalette, Gregor Murray, and Jeffrey Hilgert, professors at the School of Industrial Relations (Université de Montréal) for their constructive comments on earlier versions of this paper.

\section{NOTES}

1 The Maple Spring refers to the global social unrest that roiled the province of Quebec (Canada) in 2012. On February 13 th , 2012, major student associations launched a general strike that shuttered most of the province's colleges and universities until September $7^{\text {th }}$ of the same year. Students were mobilized for a freeze on tuition fees 
after the provincial government announced hikes of $75 \%$ over five years. Students were also reputed to be fighting against neoliberalism on the continent (Lukacs 2012).

\section{REFERENCES}

Bentley, T. and K. Oakley. 1999. The Real Deal: What Young People Really Think about Government, Politics and Social Exclusion. London: Demos.

Brown-Johnson, N. and K. Jarley. 2005. “Unions as social capital: the impact of union youth programmes on young workers' political and community engagement." Transfer 11(4):605-616.

Campbell, J. L. 2004. Institutional change and globalization. Princeton (New Jersey): Princeton University Press.

Firestein, N. and D. King. 2010. New Approaches to Organizing Women and Young Workers: Social Media and Work Family Issues. Labor Project for Working Families. Cornell ILR Labor Programs and UC Berkeley Labor Center. Retrieved February 28, 2012

(http://laborcenter.berkeley.edu/workingwomen/newapproaches10.pdf).

Freeman, R., P. Boxall and P. Haynes, (eds). 2007. What Workers Say: Employee Voice in the Anglo-American World. Ithaca NY: ILR Press.

Gauthier, M. 2011. “La précarité au Québec: un concept parmi d'autres pour parler des jeunes." SociologieS. Retrieved February 28, 2012 (http:// sociologies.revues.org/index3443.html).

Giddens, A. 1990. The Consequences of Modernity. Cambridge: Polity Press.

Gómez, R., M. Gunderson and N. Meltz. 2002. "Comparing youth and adult desire for unionization in Canada." British Journal of Industrial Relations 40 (3):521-542.

Inglehart, R. 1997. Modernization and Post-Modernization: Cultural Economic and Political Change in 43 Societies. Princeton: Princeton University Press.

Lévesque, C. and G. Murray. 2010. "Understanding union power: resources and capabilities for renewing union capacity." Transfer 16(3):333-350.

Lukacs, M. 2012, May 2nd. "Quebec student protests mark 'Maple spring' in Canada", The Guardian (UK). Page retrieved on March 12th, 2013 (http://www.guardian.co.uk/commentisfree/cifamerica/2012/may/02/quebecstudent-protest-canada).

Mahoney, J. and K. Thelen. 2010. Explaining Institutional Change: Ambiguity, Agency and Power. Cambridge: Cambridge University Press.

Nissen, B. 2004. "The Effectiveness and Limits of Labor-Community Coalitions: Evidence from South Florida.: Labor Studies Journal 29(67):67-89.

Paquet, R. 2005. "Vers une explication de la faible implication syndicale des jeunes." Revue internationale sur le travail et la société 3(1):29-60.

Peetz, D. 2010. “Are individualistic attitudes killing collectivism?” Transfer 16 (3): 383-398. 
13 Just Labour: A Canadian Journal of Work and Society - Volume 20 - Summer 2013

Tailby, S. and A. Pollert. 2011. "Non-unionized young workers and organizing the unorganized." Economic and industrial Democracy 32(3):499-522.

Usalcas, J. and G. Bowlby. 2011. "Students in the labour market, Labour Force Survey." Ottawa: Statistics Canada. Retrieved February 28, 2012 (http://www.statcan.gc.ca/pub/81-004-x/2006001/9184-eng.htm).

Vandaele, K. 2012. "Youth representatives' opinions on recruiting and representing young workers: A twofold unsatisfied demand?" European Journal of Industrial Relations 18(3):203-218.

Waddington, J. and A. Kerr. 2002. “Unions fit for young workers?" Industrial Relations Journal 33(4):298-315.

Yates, C. 2004. "Rebuilding the Labour Movement by Organizing the Unorganized: Strategic Considerations." Studies in Political Economy 74:171179. 